\title{
References
}

[1] Pokamestova, O. V. (2014). Osobennosti detei s zaderzhkoi psikhicheskoho razvitiya (ZPR) v period obucheniya v nachal'noi shkole. Problemy sovremennoi nauki i obrazovaniya, 12 (30), $126-127$.

[2] Illiashenko, T. D., Bastun, N. A., Sak, T. V. (2007). Dity iz zatrymkoiu psykhichnoho rozvytku ta yikh navchannia: navchalnyi posibnyk dlia pedahohiv i shkilnykh psykholohiv. Ministerstvo osvity Ukrainy, Instytut zmistu i metodiv navchannia. Kyiv: IZMN, 128.

[3] Dovhal, V. I. (2013). Naukove obgruntuvannia eksperymentalnoi metodyky zaniat dlia shkoliariv-pidlitkiv iz zatrymkoiu psykhichnoho rozvytku. Fizychne vykhovannia, sport i kultura zdorovia u suchasnomu suspilstvi, 1 (21), 98-102.

[4] Lesko, O. M. (2004). Orhanizatsiyno-metodychni osnovy vykorystannia rukhlyvykh ihor u fizychnomu vykhovanni molodshykh shkoliariv iz zatrymkoiu psykhichnoho rozvytku. Lvivskyi derzhavnyi instytut fizychnoi kultury, 20.

[5] Hvozdetskaia, S. V. (2008). Korrektsiya pokazatelei pamiati u detei 6 let s zaderzhkoi psikhicheskoho razvitiya sredstvami fizicheskoho vospitaniya. Pedahohika, psikholohiya i mediko-biolohicheskie problemy fizicheskoho vospitaniya i sporta, 7, 31-33.

[6] Naboikina, E. (2008). Intehrativnaia korrektsionno-razvivaiushchaia prohramma reabilitatsiyi i adaptatsiyi detei s osobennostiami psikhofizicheskoho razvitiia. Shkol'nyi psikholoh. Izdatel'skiy dom «Pervoe sentiabria», 17, 7-14.

[7] Shmarhun, V. M. (2010). Vikovi ta indyvidualni psykhosomatychni osoblyvosti ditei yak predyktory rozumovoho rozvytku (molodshyi skilnyi i pidlitkovyi vik). Natsionalnyi pedahohichyi universytet imeni M. P. Drahomanova, 39.

[8] Liakh, V. I. (2006). Koordinatsionnye sposobnosti: diahnostika i razvitie. Moscow: TVT Divizion, 290.

[9] Tuchak, O. A., Romaniuk, V. P., Kots, M. O. (2015). Osoblyvosti vzaiemozviazkiv koordynatsiinykh zdibnostei iz psykhichnymy protsesamy ta vlastyvostiamy $\mathrm{v}$ molodshykh shkoliariv iz zatrymkoiu psykhichnoho rozvytku. Fizychne vykhovannia, sport i kultura zdorovia u suchasnomu suspilstvi, 4 (55), 196-200.

[10] Anokhin, P. K. (1980). Uzlovye voprosy teorii funktsional'noi sistemy. Moscow: Nauka, 196.

[11] Bashtan, S. O., Shmaliei, S. V. (2015). Vzaiemozviazok funktsionalnoi ta fizychnoi pidhotovlenosti ditei molodshoho shkilnoho viku z zatrymkoiu psykhichnoho rozvytku. Pryrodnychyi almanakh, 15, 5-13.

\section{THE TRENDS OF CURRENT VOCATIONAL EDUCATION AND TRAINING REFORMS IN LUXEMBOURG: REVIEW AND ANALYSIS}

\author{
Olesia Samokhval \\ Department of Innovation and Information Technologies in Education \\ Vinnytsya Mykhailo Kotsiubynsky State Pedagogical University \\ 32 Ostrozkogo str., Vinnytsia, Ukraine, 21100 \\ samohvallesya@ukr.net
}

\begin{abstract}
The article deals with the theoretical analysis and grounding of current reform trends in the educational system of the Grand Duchy of Luxembourg, particularly in vocational education and training, as well as identifies the backgrounds for reforming the system of vocational education and training, and directions of activity for the implementation of the set tasks. In the course of the study, the problems faced by the Luxembourg vocational education and training were studied. They have both geopolitical and socioeconomic characteristics and comprise: low level of pupils' performance in basic subjects; multilinguism; insufficient coherence of vocational training offers with the needs of the labor market within the country and in Europe; low rate of the labor force, that completes the full range of vocational education and training; insufficient development of vocational training in the tertiary level system.
\end{abstract}


Having examined the content of the well-established and drafted laws and acts, we have identified certain trends observed in the reform of the Luxembourg vocational education and training, namely: standardization of vocational education and training in accordance with the European educational standards; focusing on the secondary vocational education and training reforming; adoption of the best traditions of future skilled workers training from neighboring countries (Germany, Austria, Switzerland); international educational cooperation of Luxembourg that will provide the country with highly qualified workers.

Keywords: vocational education and training, higher education, the Grand Dutch of Luxembourg's education system, lifelong learning, employment, reforms.

\section{Introduction}

Nowadays vocational education and training (VET) is becoming not a crossboundary and transnational factor of the effective social development, a leading area for the formation of highly qualified and competitive workers capable of immediate respond to rapid changes in working conditions, growing volumes of technical science knowledge, globalization and informatization of all the spheres of social life, but also the main national and world priority.

In relation to developing countries, bilateral aid agencies, the World Bank and United Nations Educational, Scientific and Cultural Organization (UNESCO) advocate vocational education to reduce poverty, promote economic growth and increase competitiveness [1]. In a European context, it is seen as a major tool in the transformation of the European economy [2] and there are numerous examples of presumed effects in countries, regions and specific sectors of the economy [3].

Nevertheless, deep civilization changes and new socio-economic realities of the market economy require the rethinking and restructuring of the VET structure, as economies change, so too must vocational education and training [4]. Reference within our research to the small countries of Western Europe, such as Luxembourg, turns out to be very challenging. In recent years, it has made a significant progress not only in increasing of the gross national product, raising the quality of life and productive competence of the population, but also in reforming the educational system, specifically vocational education and training.

Another important thing is to highlight current trends in the national socioeconomic context while examining the development of VET, its appeal and qualitative results, the reforms and their influence on the economic development of Western European countries. Analysis of vocational training in various types of educational establishments in Luxembourg indicates that VET is characterized by a dual system of training that was extrapolated from the experience of Germany. Together with it, the differentiated VET of the country comprises the curriculum that performs certain vocational training functions characterized by the VET system of France. This suggests that borrowing of the better experience of future skilled workers' vocational training in European countries and its transformation into the national educational system of Luxembourg is a peculiar feature of this country, and deserves careful examination and analysis.

\section{Aim of research}

The research is intended to analyze and investigate theoretic backgrounds of current reform trends in the educational system of Luxembourg, particularly in VET; to distinguish the causes and consequences of its reforming; identify the principles and directions of activity for the implementation of the set tasks.

\section{Reforming secondary vocational education and training of Luxembourg}

The Grand Dutch of Luxembourg, a country of 2, 586 square kilometers, with a population of 582,972 (2016 census) and a trilingual education system moves toward increasing competitiveness in the global economic market. The problem of future skilled workers' vocational training is the need-of-the-hour being one of the main element of a new quality professional potential's building and that corresponds to the conceptual framework of the country's socio-economic development. 
With the official start of the Luxembourg Presidency of the Council of the EU (2015), the period of enhanced European cooperation in VET was established. In June 2015, the responsible European ministers for vocational education and training met in Riga for the conference "Innovating for the Future of VET". Together with representatives of the social partners and the European Commission they discussed the future challenges in the working world and defined deliverables on an EU level for the period 2015-2020 to boost employability and competitiveness [5].

It should be noted that the activity on creating a European educational area is coordinated and provided by various organizational structures. There is an estimated set of legislative and regulatory assets of foundation for reforming the system of higher education and VET in the European Union, and the corresponding sociopolitical and economic prerequisites for restructuring and improvement of the national educational systems of the EU member-states [6].

Several perspectives and objectives being achieved by EU member countries are reflected in Luxembourg's system of VET, namely:

- finding an adequate balance between benefits and clarity of VET;

- developing closer ties with the business world and labor market being a prerequisite to efficiency and relevance to labor market needs;

- provide constant improvement of vocational skills within lifelong learning, irrespective of linguistic, cultural and socio-economic status.

It is also reflected in the National Qualifications Framework and the relevant references to this document, or in implemented reforms, for example the reform of vocational education and training in Luxembourg of 2008, that have been resulted in focusing on the learning outcomes and the introduction of a modular approach to the development of vocational training programs.

The VET reform of 2008 has created the legal framework for the adaptation of the VET system to the current realities of the society and the labor market.

It was mainly focused on:

- promotion of VET;

- improving the quality of VET and facilitating the access to lifelong learning;

- strengthening partnerships with the business world;

- the use of teaching and assessment methods based on the development of competences;

- replacement of learning courses by training units and modules focused on specific job situations;

- determination of training results by the acquired competencies and knowledge defined for each individual module;

- assessment and certification of apprenticeship accordingly learning results;

- training of teachers for a vocational school;

- the introduction of the notion "teachers for adults in certain fields of vocational activity";

- improvement of cooperation between the state and social partners.

The reform of VET of 2008 (with amendments in 2014) was intended primarily to improve the quality of providing VET at secondary schools. The implementation of the main issues was carried out in two periods: first - 2010/11; second - 2013/14 [7].

Secondary VET in Luxembourg is based on a dual system that includes education at school, training in a private or state enterprise, as well as international cooperation with vocational enterprises of neighboring countries. In this context, an interesting fact illustrating Luxembourg as a country of educational and job mobility in Europe is a cross-border training for VET. It shows that education without borders, the most common in higher education sector, can also be applied in the system of secondary VET and carry out in different forms. Such forms of secondary vocational schools' cooperation in providing dual training, for example, vocational training cooperation with neighboring countries (Germany, Austria), indicate the possibility of changing the geographical location (an enterprise is located in Luxembourg, and a vocational school - in Germany).

Still, most of the changes under the Reform of VET involved the provision for financial compensation to an employer in return to the services provided by the employer to the students during their practical training at the enterprise, as well as increasing number of basic vocational training programs in certain profile. Hence, the closer interaction between the state and business partners 
within the Committee on VET of Luxembourg was directed at ensuring a joint development of training programs for future skilled workers who would be able to meet the needs of the national and world labor market [8].

Nevertheless, despite the close cooperation between Luxembourg and the Council of Europe on education matters and the ongoing efforts to reform the national educational sector, some urgent issues need to be reviewed. The key problem of Luxembourg's secondary education was identified in the European Semester Country Report 2016. It was reported that the performance of apprenticeship in basic skills (mathematics, reading and natural sciences) assessed within the Programme for International Student Assessment of the Organization for Economic Cooperation and Development (PISA) is lower than the EU average. It can be explained, mainly, by students' socioeconomic status and immigration background. It is shown not only by gained data on basic skills but also by statistics on dropout, whose amount is relatively high among immigrants.

Migration background however is one of the challenges to be tackled in the Luxembourgish education system. National intention to resolve the problem of quick adaption of immigrants to the well-being of Luxembourgish citizenship can be explained by the fact that non-natives are over-represented with relation to Luxembourg nationals. Besides, Luxembourg's blue-collar working-class are mostly represented by immigrants providing the country`s economy with necessary and even deficit labor force.

Luxembourg's trilingual education system is another challenge for its highly diverse student population. Still, having analyzed the lingual aspect of the education system in Luxembourg, we should admit that the Luxembourg government has clearly set language priorities due to education levels. It means that Luxembourgish is spoken at home and at institutions of pre-school education, German is used for teaching children in primary schools. In general, secondary education, French is used for teaching mathematics and gradually extended to the other subjects. The dominant language in secondary vocational education is German, with French used in mathematics. So, entering higher education institutions, school leavers should not face any linguistic obstacles and can choose a higher degree program suited to their abilities, not to language fluency. However, the use of both, German and French, languages in secondary education could have caused the problem of low performance of apprenticeship in basic skills. Therefore, in 2015, the Council of Luxembourg adopted a bill on youth support provided various linguistic support measures, including language training of children between the ages of 1 and 3. This step has been fully appreciated by the society and demonstrated another aspect of the reform trends in the education sector.

\section{National Framework of Qualifications}

Another important step in reforming VET was the development and approval of the Luxembourg Qualifications Framework. The Luxembourg Qualifications Framework is intended to serve as a non-binding guidance framework for individuals, providers of education and training and for the employment market. It will enable individuals to rank their qualifications in relation to other qualifications, with a view to lifelong learning. A further element of the Luxembourg qualifications framework is its intention not only to apply to the formal system of qualifications but also to include non-formal qualifications [2].

It should be noted that the process of adoption of Luxembourg Qualifications Framework was not an easy one followed by numerous consultations and discussions within the country and the European Union. In 2005, after numerous consultations on the adoption of the European Qualifications Framework, the Grand Duchy of Luxembourg made a positive decision, although some misgivings were expressed. In Luxembourg`s written request to the European Commission it was emphasized that a relatively unique national qualification framework was in a state of developing and needed time to be completed through consultations with EU member countries in order to correspond to their systems. In such a way, Luxembourg has demonstrated the importance of cooperation with European countries in educational issues and the national interest in this approach. This could be explained by three reasons:

- the ability to focus on competence as a result of learning activity that should be in line with the idea of adapting the national education system to European one and vocational training of a qualified staff of a certain profile; 
- the approval of the qualification framework facilitates;

- the recognition of qualifications acquired in other EU member countries;

- recognition of the qualifications issued in other EU countries by Luxembourg's authorities considering the situation in the national labor market and immigration trends.

Having adopted the Recommendations of the European Parliament and of the Council of 23 April 2008 on the establishment of the European Qualifications Framework for lifelong learning, Luxembourg's Ministry of Education and Vocational Training in cooperation with the Ministry of Higher Education and Research submitted the draft of the National Qualifications Framework for the Grand Duchy of Luxembourg (NQFL) for consideration and discussion by different organizations concerned. The document was developed in compliance with the existing national framework of qualifications and the qualifications frameworks of neighboring countries. In 2009, the Council of Government of Luxembourg took the draft of the National Qualifications Framework for consideration and then provided the consultations between ministries. In September 2010, the Council of Government adopted the final variant of the document and submitted it to the concerned group (social partners, representatives of chambers, representatives of secondary and vocational schools and the University of Luxembourg) [9].

We believe, developing of the National qualifications framework of Luxembourg, is a part of the initial stage of reform decisions taken to contribute to the further modernization of the educational sphere of the country. It is based on standards of knowledge, skill and competence and incorporates gained awards made for all kinds of learning. Besides, it corresponds to the European Qualifications Framework concerning lifelong education and training and links to other countries to ensure that qualifications frameworks are connected internationally.

Reforming higher education of Luxembourg

Higher education of the Grand Duchy of Luxembourg is governed by two laws: the Education Act of August 12, 2003, creating the University of Luxembourg [10]; Law of 19 June 2009, establishing a national system of higher education [11].

The aim of the Law of 12 August 2003 was to create the University of Luxembourg. It should be noted that, by 2003, there hadn't been any university in the Grand Duchy of Luxembourg. The Law of 19 June 2009 defined the framework of higher education and created the legal foundation for the development of new high degree programs. Besides it laid down the framework of legislation necessary for accrediting high degree programs organized by private or public establishments, whether Luxembourgish or otherwise, but established in the Grand Duchy. Higher education in the Grand Duchy is aligned with the structuring provided for in the Bologna Process, and hence comprises an initial short cycle followed by three university cycles [9].

Being a small country, the main reason for the lack of tertiary vocational education institutions, Luxembourg is trying to expand its cooperation with its neighboring countries attracting high-quality workforce for the national economy. For this reason, in May, 2015, the Benelux countries signed an agreement for mutual recognition of higher education diplomas [7]. The document was adopted by the Minister of Education for Children and Youth, the Minister of Labor and Employment, as well as public and private institutions of vocational education in the Greater Region. The main task of the agreement is to structure existing cross-border projects in identifying the general objectives of VET and labor mobility in the Greater Region. The targeted efforts of the agreement also include ongoing training of low-skilled persons and proposals for those who are seeking employment, mainly young people.

Thus, within the Great Region, the agreement on cooperation seeks to intensify labor market integration and mobility, especially among young people; reduce unemployment rate; recognize qualifications; intensify cooperation on cross-border VET; eliminate regulatory obstacles. However, the signed agreement regulates the most important issues of VET nationwide, namely:

- mutual recognition of diplomas and competencies;

- obtaining a diploma in two different countries;

- gaining of professional skills and abilities in the vocational training in other country;

- creating a network of relevant services such as ministries, employment centers and youth

offices to promote vocational training and release the process of employment;

- strengthening support for cross-border workers. 
In order to support students of higher education institutions in Luxembourg and promote transnational research mobility, the House of Representatives of Luxembourg adopted a regulation law of June 30, 2016, as an amendment to the Law of July 24, 2014 on state financial assistance to higher education graduates. Proposed amendments guarantee increasing grant financing - the mobility grant amounts to 2,450 Euro per year (instead of 2000 Euro earlier) and a social bursary amounts to 3800 Euro (instead of 3000 Euro earlier); flexibility of grant assistance in accordance with the indexation of wages in the country; some technical amendments regulating the procedure of grant financing by higher education institutions and the tools of avoiding simultaneous granting by different organizations. The new law of July 23, 2016 came into force on August 1, 2016, with the exception of the provisions related to the indexation of grant assistance that was applied on August 1, 2017 [12].

During the 2013-2014 academic year the reform of the state financial assistance in higher education for children of cross-border workers was implemented. The reform was carried out in the 2014-2015 academic year and came into force in August 2014 with the adoption of the law of July 24, 2014 "On State Financial Assistance for Higher Education". According to the Law, the components of financial assistance for study at the University are loans and grants divided into different categories: major grants, mobility grants and social bursary. Unlike the previous legislation, the new system has a modular structure that implies an element of social selectivity. A significant increase in assistance for higher education in the 2013-2014 academic year was made by the European Court of Justice's decision C-20/12 that required to grant children of cross-border workers with the social subsidies.

Active financial support of higher education and the development of scientific researches by the Government should be also admitted. State financial payments to the University of Luxembourg are constantly increasing. For example, state funding of the university has increased from 72 million Euros in 2009 to 101.6 Euros in 2012, in 2016 it amounted to 154.1 Euros. Consequently, the number of students increased from 4934 in 2009-2010 to 6172 in 2015-2016 [13].

At the same time, the lack of higher education institutions causes the constant increase of educational mobility guaranteeing Luxembourg citizenship high-quality vocational education abroad. Unfortunately, this tendency does not provide the country with corresponding education immigration.

\section{Results of the research and discussion}

The national plan for the smart, sustainable and inclusive growth 2020 published in 2017 is a National Reform Program of the Grand Duchy of Luxembourg that fully coincides with the European Strategy for Sustainable Growth, Europe 2020 identifying key policy issues and measures for promoting the economic growth and social inclusion within Europe. Reducing the dropout rate below $10 \%$ of the total number of apprenticeships and increasing at least up to $66 \%$ of the working population received tertiary or equivalent education between the ages of 30-34 years has been identified as national educational targets of Luxembourg to be realized by 2020 [13].

The Luxembourg Youth Guarantee Program (2014) is a significant example of Luxembourg's efforts to improve the situation with early leavers. It offers individual programs for people aged 16-24 who are intended to continue education and find or improve his/her position in the labor market.

Having signed an agreement (Benelux agreement) on recognition of academic degrees, in 2015, qualifications endowed by Bachelor's and Master's degrees in Belgium, the Netherlands and Luxembourg are automatically recognized by the countries [6]. The main purpose of the document is to facilitate the mobility of students and labor force within the Benelux region.

It should be underlined that the number of students (mainly from immigrant families) at the secondary education level in Luxembourg enrolled in vocational programs is significantly higher than in other Western European countries (average percentage in Luxembourg is $60 \%$, Western European countries $-46 \%$ ). Still, the percentage of skilled workers completing the full cycle of vocational training is very low: $29 \%$ of students enrolled in vocational programs (compared with the average $64 \%$ in the Western countries). 
To reduce the dropout rate in 2016 the Ministry of Education, Children and Youth of Luxembourg developed a new training program that is equivalent to the completion of a comprehensive school and foresees obtaining an admission diploma (Fran. Diplôme d'accès aux études supérieures) to continue education at higher education institutions. In Luxembourg, this diploma provides entering not only a university, but also getting a certain job in the public sector. Developed within the framework of lifelong learning, the educational project "Second Chance School" (Fran. École de la deuxième chance) started training of future students at the beginning of the 2016-2017 academic year. The target audience was people of age 20 who left school at least 2 years ago and had 12 months working experience (20 hours per week). Depending on the education level of the future graduate, the course lasted one or two years, completing with the compulsory final examination [14].

Having analyzed the recent data of statistics, we must admit, Luxembourg`s plan to provide $66 \%$ of the population aged 30 to 34 with the opportunity to get higher educational degree by 2020 is successfully fulfilling. The number of people acquired Diploma of Higher Education or higher vocational education has increased from $36 \%$ in 2006 to over $50 \%$ in 2015. Another way of implementing the national educational objectives is to expand the offer of state and private higher educational programs. In May 2015, three additional short-term professional programs directed to getting of the technical certificate (Eng. BTS technical certificate course) were accredited. As a result, the number of accredited higher vocational programs increased to 24 in the 2015-2016 academic years.

The role of universities should be also admitted in achieving the goals set by the National Reform Program of the Grand Duchy of Luxembourg. Having analyzed the education activity of the University of Luxembourg and private higher education institutions (BBI Wiltz School for Hospitality Business; Luxembourg Business; Luxembourg School of Business; Sacred Heart University; UBI Wiltz United Business Institutes) located in the country, we found out that they are intended to release the access of the population to the academic degree programs (Bachelor and Master programs) in order to raise the amount of citizenship obtained a tertiary degree or its equivalent. Thus, universities offer school leavers to entry academic or vocational training programs with a general or professional maturity certificate (Fran. diplôme de fin d'études secondaires; certificat de capacité professionnelle) without setting priorities. In addition, non-native students can be enrolled at higher education institutions with a General Certificate of Secondary Education issued by a foreign school equivalent to a national maturity certificate. This fact demonstrates the intention of Luxembourg's higher education institutions to increase the level of student mobility facilitating access to academic or vocational programs, thereby expanding educational opportunities for themselves.

Besides, applying for a master's degree program in a particular specialty, it is not necessary to acquire a lower academic degree in the same profile. Students should only obtain a bachelor's diploma or a specialized diploma of higher education. For retraining in further studying at the desired master's degree program, higher institutions offer an introductory year for Master Curriculum to further students' academic balancing.

Another peculiarity of studying at the Master's program at Luxembourgish higher education institutions is the necessity of having work experience indicated in the diploma given by entrance, and in some cases, the current workplace. It indicates the higher institutions implementation of one of the most important national task to raise the education level of the country's labor force. Universities, in their turn, create flexible academic timetable, introducing weekend (Weekend MBA Format) or evening classes. Therefore, we can say that Luxembourg has finally determined the priority directions of the development of national VET in which education institutions of the country's secondary and higher educational levels are actively involved.

Understanding the importance of highly qualified workforce's training that secures the country with the competitiveness and innovation, facilitates the regulatory process in a changing economic market, Luxembourg is demonstrating strong performance in realization of objectives necessary for its implementation within the VET system. We are convinced that Luxembourg's experience in reforming the VET is comprehensive and prosperous and can be successfully used by other countries. 


\section{Conclusions}

1. It is revealed that Luxembourg's vocational education faces problems that posses geopolitical and socioeconomic features and require urgent solutions. The issues referred to secondary VET can be defined as the low level of academic performance of apprenticeship on basic subjects; insufficient coherence of vocational training offers with the needs of the national and European labor market; a low rate of workforce completing a full cycle of VET. The system of tertiary level of VET is not sufficiently developed giving rise to the educational migration of Luxembourg's citizenship. Besides, multilingualism as a national identity causes the problem of poor-quality performance of pupils and students from immigrant families, whose great part represents the labor force of Luxembourg.

2. Having investigated the content of the laws, amendments to the laws and acts adopted over the last decades, we have identified some trends been observed in the reforming of Luxembourg's VET, namely:

- standardization in VET in accordance with European standards of VET by taking into account the recommendations of the European Council on Education;

- focusing on the reforming of secondary vocational education as the main supplier of labor force and the basic component of VET on tertiary level of education system in order to provide the country with highly qualified managerial staff;

- adoption of the best experience of future skilled workers training in neighboring countries (Germany, Austria, Switzerland) making good educational sense;

- international educational cooperation providing the country's economy with highly skilled personnel.

3. Consequently, Luxembourg's VET reforming is based on the European benchmark criteria and highly depends on the legal rules which regulate the economic system, such as the division of labor, competition, the concept of exchange, being extremely important in providing the maintained social and economic development.

\section{References}

[1] Comyn, P., Barnaart, A. (2010). TVET reform in Chongqing: big steps on a long march. Research in Post-Compulsory Education, 15 (1), 49-65. doi: 10.1080/13596740903565335

[2] The Bordeaux Communiqué on enhanced European cooperation in vocational education and training (2008). Available at http://www.sepe.es/contenidos/personas/formacion/refernet/pdf/Bordeaux Communique_EN.pdf

[3] Budría, S., Telhado-Pereira, P. (2009). The contribution of vocational training to employment, job-related skills and productivity: evidence from Madeira. International Journal of Training and Development, 13 (1), 53-72. doi: 10.1111/j.1468-2419.2008.00315.x

[4] Mupimpila, C., Narayana, N. (2009). The role of vocational education and technical training in economic growth: a case of Botswana. International Journal of Education Economics and Development, 1 (1), 3. doi: 10.1504/ijeed.2009.028935

[5] Bilateral Agreements and Worldwide Cooperation. Official website of Eurydice. Available at: https://eacea.ec.europa.eu/national-policies/eurydice/content/bilateral-agreements-and-worldwide-cooperation-25_sr

[6] European Commission/EACEA/Eurydice, 2015. The European Higher Education Area in 2015: Bologna Process Implementation Report. Luxembourg: Publications Office of the European Union, 304.

[7] Vocational education and training in Luxembourg: short description (2015). Luxembourg: Publications Office. Cedefop information series, 92. Available at: http://www.cedefop.europa.eu/files/4141_en.pdf

[8] National plan for smart, sustainable and inclusive growth (2016). Luxembourg, 45. Available at: https://ec.europa.eu/info/sites/info/files/european-semester-national-plan_luxembourg_2016_en.pdf

[9] Education Policy Outlook. Available at: http://www.oecd.org/education/policyoutlook.htm

[10] University of Luxembourg, Official Documents. Available at: https://wwwen.uni.lu/university/ official_documents

[11] Bianca Faragau-Tavares (2016). Country report: Luxembourg 2016. Update to the European inventory on validation of non-formal and informal learning. Cedefop, 25. 
[12] Mémorial A n 143 de 2016 [Amendment A to the Law n 143 2016]. Journal officiel du GrandDuché de Luxembourg [Official newspaper of the Grand Duchy of Luxembourg]. Available at: http://legilux. public.lu/eli/etat/leg/memorial/2016/143?highlight=enseignement $\% 22$ sup $\% 20 \% \mathrm{C} 3 \% 20 \% \mathrm{~A} 9$ rieur

[13] National plan for smart, sustainable and inclusive growth 2020 (2016). Luxembourg.

[14] National Reforms in Vocational Education and Training and Adult Learning. Luxembourg. Available at: https://webgate.ec.europa.eu/fpfis/mwikis/eurydice/index.php/Luxembourg:National_Reforms_in_Vocational_Education_and_Training_and_Adult_Learning

\title{
VALUE GAPS IN THE PLANETARY MATRIX OF THE WORLD COMMUNITY AS A LIMITROPHE OF WAR AND PEACE
}

Bohdan Kalinichenko

Department of Civil Service, Public Administration and Political Science

Bohdan Khmelnitsky National University of Cherkasy

81 Shevchenko blvd., Cherkasy, Ukraine, 18031

555tvukraine@vu.cdu.edu.ua

\begin{abstract}
The article describes the problem of spontaneous transformation of the planetary matrix of the social world, moving from the cell to the network structure, resulting not only in the changes of the world system of the planetary community, the shapes of national states are melting out gradually, the need for cosmopolitan world perception and thinking of the political elite arises, the managing processes come into the picture, hybrid planetary policy is formed, and finally, qualitatively new conflict forms and even hybrid wars appear. With the change in the planetary matrix structure, there are several fundamental changes in the life-plan of a planetary human being, since the fundamentally different segments of archetypes are activated in the world community's subconsciousness, the values-semantic substrates are mixed in the consciousness, and completely different logical schemes and algorithms of influence on a person are activated in the noosphere. At the same time, this means that in the sphere of national powers the emphasis of state policy, state regulation and public administration tends to shift from the territorial horizon into the plane of regulation of world planetary processes. This tendency also transfers the focus of their organizational efforts from the national and state levels to the political space of interstate and supra-state entities. The most intense points of relations between the actors of the modern integral process are the so-called limitrophes and frontiers.
\end{abstract}

Keywords: civilization, matrix, transformation, cell structure, network, fault, cosmopolitan consciousness, limitrophe, frontier, hybrid war.

\section{Introduction}

Lately, the modern planetary world has been in the state of actual unsolemn permanent war. Today, it has a different degree of cruelty in more than forty locations on the planet. It acquires qualitatively new features, for example, becomes hybrid when the boundary between "us" and "them" actually disappears. The confrontation moves into the consciousness of the average person, which generates the fear and uncertainty of the entire peoples in the future on a mass scale.

Therefore, it became an acute practical and theoretical problem at the beginning of the XXI century. And it is related to the fact that this is not only about the lost lives of dozens, if not hundreds of thousands of people, and the huge loss of material wealth of the peoples, who have been building a practical basis for their own livelihoods for decades, but also about our theoretical and practical misunderstanding of what is happening with the consciousness of the planetary humanity, which, under the pressure of the generally accepted processes of globalization, informatization and significant increase in the capacity of international communication networks, must become more and more planetary, i. e., one that understands the common problems of the world community and is aimed at their positive solution. 